\title{
Rapid and specific influenza virus detection by functionalized magnetic nanoparticles and mass spectrometry
}

Tzu-Chi Chou', Wei Hsu' ${ }^{2,3}$, Ching-Ho Wang ${ }^{4}$, Yu-Ju Chen ${ }^{1,2,3^{*}}$ and Jim-Min Fang ${ }^{1,5^{*}}$

\begin{abstract}
Background: The timely and accurate diagnosis of specific influenza virus strains is crucial to effective prophylaxis, vaccine preparation and early antiviral therapy. The detection of influenza A viruses is mainly accomplished using polymerase chain reaction (PCR) techniques or antibody-based assays. In conjugation with the immunoassay utilizing monoclonal antibody, mass spectrometry is an alternative to identify proteins derived from a target influenza virus. Taking advantage of the large surface area-to-volume ratio, antibody-conjugated magnetic nanoparticles can act as an effective probe to extract influenza virus for sodium dodecylsulfate polyacrylamide gel electrophoresis (SDS-PAGE) and on-bead mass spectrometric analysis.

Results: Iron oxide magnetic nanoparticles (MNP) were functionalized with H5N2 viral antibodies targeting the hemagglutinin protein and capped with methoxy-terminated ethylene glycol to suppress nonspecific binding. The antibody-conjugated MNPs possessed a high specificity to H5N2 virus without cross-reactivity with recombinant H5N1 viruses. The unambiguous identification of the captured hemagglutinin on magnetic nanoparticles was realized by SDS-PAGE visualization and peptide sequence identification using liquid chromatography-tandem mass spectrometry (LC-MS/MS).

Conclusions: The assay combining efficient magnetic separation and MALDI-MS readout offers a rapid and sensitive method for virus screening. Direct on-MNP detection by matrix-assisted laser desorption/ionization timeof-flight mass spectrometry (MALDI-TOF MS) provided high sensitivity $\left(\sim 10^{3} \mathrm{EID}_{50}\right.$ per $\left.\mathrm{mL}\right)$ and a timely diagnosis within one hour. The magnetic nanoparticles encapsulated with monoclonal antibodies could be used as a specific probe to distinguish different subtypes of influenza.
\end{abstract}

Keywords: Viruses, Influenza, Hemagglutinin, Magnetic nanoparticles, Mass spectrometry, Gel electrophoresis

\section{Background}

Influenza remains a major health problem for humans and animals. The recent cross-species transmission of avian influenza viruses to humans has raised a great concern for the possible global pandemic threat if the viruses become transmissible among humans.

Influenza viruses can be classified into types A, B and C. These subtypes are further designated according to the serological cross-reactivity of the antibodies against hemagglutinin (HA) and neuraminidase (NA), which are the most important glycoproteins on the surface of

\footnotetext{
* Correspondence: yjchen@chem.sinica.edu.tw; jmfang@ntu.edu.tw 'Department of Chemistry, National Taiwan University, Taipei, 106, Taiwan Full list of author information is available at the end of the article
}

influenza virus with critical roles in virus infection and transmission. To date, $16 \mathrm{HA}(\mathrm{H} 1-\mathrm{H} 16)$ and 9 NA (N1N9) subtypes in influenza A viruses have been isolated from avian species. HA is translated as a single polyprotein, $\mathrm{HA}_{0}$, which exists in a trimeric assembly $[1,2]$. The transmembrane protein $\mathrm{HA}_{0}$ consists of two polypeptide chains, $\mathrm{HA}_{1}$ and $\mathrm{HA}_{2}$, linked by inter-chain disulfide bonds. For viral activation, $\mathrm{HA}_{0}$ must undergo an enzymatic cleavage to give two functional subunits, $\mathrm{HA}_{1}$ and $\mathrm{HA}_{2}[1,2]$. Highly pathogenic avian influenza viruses, such as $\mathrm{H} 5 \mathrm{~N} 1$, contain many basic amino acid residues in the cleavage site of $\mathrm{HA}_{0}$ and are thus easily activated by trypsin and other proteases for systemic infection $[1,2]$.

\section{Biomed Central}

(c) 2011 Chou et al; licensee BioMed Central Ltd. This is an Open Access article distributed under the terms of the Creative Commons Attribution License (http://creativecommons.org/licenses/by/2.0), which permits unrestricted use, distribution, and reproduction in any medium, provided the original work is properly cited. 
At present, four drugs are approved for influenza prophylaxis and treatment [3-5]: amantadine and rimantadine act as M2 ion channel blockers, and Tamiflu ${ }^{\mathrm{TM}}$ (the phosphate salt of oseltamivir) and Relenza ${ }^{\mathrm{TM}}$ (zanamivir) inhibit the activity of NA. For the most effective treatment, these anti-influenza drugs are recommended for use within $48 \mathrm{~h}$ of the onset of influenza symptoms because proliferation of the virus reaches a peak after 2 days of infection. Thus, timely and accurate diagnosis of specific influenza virus strains is crucial for effective prophylaxis, vaccine preparation and early antiviral therapy.

The detection of influenza A viruses is mainly accomplished using polymerase chain reaction (PCR) techniques or antibody-based assays to identify the relatively abundant nucleoproteins (NP) [6-13]. Because NP is only a type-specific protein, subtype- or strain-specific diagnosis cannot be achieved. For the specific detection of influenza viruses using real-time reverse transcription-polymerase chain reaction (rRT-PCR) [6-9], choosing proper primer pairs for subtyping becomes critical. Although sequence-based diagnosis often shows high sensitivity, the experimental procedures are tedious and may give false results.

According to a recent survey [8], the commercially available influenza diagnostic kits based on rRT-PCR can be used to detect $\mathrm{H} 1 \mathrm{~N} 1$ virus with a limit of detection in the range of $10^{4.5}-10^{5.5} \mathrm{TCID}_{50}(50 \%$ tissue culture infective dose) per $\mathrm{mL}$. However, a negative result does not rule out possible infection with influenza virus due to the overall low sensitivity (40-69\%) of the diagnostic kits [8]. In contrast, an antigen capture immunoassay with specific monoclonal antibodies [10-13] is often utilized in rapid influenza diagnostic tests. An investigation into the commercially available test kits indicated that $10^{4.7}$ mean embryo lethal dose $\left(E L D_{50}\right) /$ $\mathrm{mL}$ of avian influenza viruses in allantoic fluid can be detected by an antigen capture immunoassay [10].

The low sensitivity in antigen tests may be problematic in dealing with untreated samples due to nonspecific interactions with other proteins. The antigencapture enzyme-linked immunosorbent assay (ELISA) has been explored to distinguish subtypes of influenza viruses with better sensitivity than immunoassays [11]. However, ELISA is time consuming and usually takes prolonged times ( $\sim 12$ hours) to provide results.

Alternative methods have been investigated for viral detection, including surface plasmon resonance [14], multiplexed flow cytometry [15], quartz-crystal microbalance [16], mass spectrometry [17-19], and microarrays [20-26]. With the power of peptide sequencing and database searches for unknown protein identification, however, mass spectrometry has been considered as one of the gold standard methods for protein analysis due to its low detection limit, rich structural information, and, most importantly, high accuracy. The Yip group was one of the first to integrate affinity capture techniques with direct mass spectrometric detection of target proteins from a complex mixture [27]. The concept was advanced further by Nelson and coworkers in the development of a mass spectrometric immunoassay (MSIA) using affinity pipette tips to selectively detect proteins and their variants [28-30]. Despite these existing methodologies, to our knowledge the application of affinitybased mass spectrometric methods for detection and identification of flu strains remains unexplored.

In combination with immunoassays utilizing monoclonal antibodies, mass spectrometry is especially useful for the identification of proteins derived from a target influenza virus. Mass spectrometry is not only applicable to confirm the subtype of virus but is also a powerful tool for the identification of the antigenic determinants on the viral HA [17-19]. Prior enrichment of the viral antigen is often utilized to improve the detection sensitivity and the coverage of peptide sequence identification in the mass spectra. An effective method for viral antigen enrichment using surface functionalized magnetic nanoparticles is pursued in this study.

Taking advantage of the large surface area-to-volume ratio and the unique chemical and physical properties of nanoparticles, a considerable number of studies on surface functionalization have been reported for biomedical applications. Among the various types of nanoparticles, magnetic nanoparticles (MNPs) have attracted increasing attention for the advantage of efficient separation from complex mixtures with a magnetic field [31-39]. This unique characteristic of MNPs surpasses traditional solvent intensive and time-consuming purification methods.

As demonstrated in our previous study [36,37], antibody-conjugated MNPs with proper surface protection act as efficient affinity probes for the rapid extraction of target proteins from human plasma. Because HA proteins are located on the surface of influenza viruses, MNPs modified with HA antibodies can be envisioned as an effective nanosensor for rapid detection of influenza viruses. Through this MNP-assisted mass spectrometry-based immunoassay, we expect to develop a simple and fast virus screening assay with unambiguous identification. H5N2, an avian influenza virus with low pathogenicity, and recombinant $\mathrm{H} 5 \mathrm{~N} 1$ pseudo-viruses were utilized as proof-of-concept model systems to evaluate the assay performance in terms of sensitivity and specificity. The data demonstrated the combined use of the antibody-MNP and MALDI-MS methods for the sensitive detection of influenza viruses and rapid screening of virus subtypes. The specificity of HA enrichment was confirmed by sodium dodecylsulfate polyacrylamide 
gel electrophoresis (SDS-PAGE) and peptide mass sequencing using liquid chromatography-tandem mass spectrometry (LC-MS/MS).

\section{Results and discussion}

- Preparation and characterization of ethyleneglycolprotected anti-HA antibody-conjugated magnetic nanoparticles

The synthetic scheme for the antibody-conjugated MNPs is detailed in Figure 1A. The iron oxide nanoparticles $\left(\mathrm{Fe}_{3} \mathrm{O}_{4}\right)$ were prepared by mixing $\mathrm{FeCl}_{2}$ and $\mathrm{FeCl}_{3}$ under basic conditions according to the previously reported procedure [40]. Through treatment with 3-aminopropyltrimethoxysilane (APS), the aminosilane coated MNPs (AS@Fe $\mathrm{O}_{3}$ MNPs) exhibited an increased stability and contained amino groups for surface functionalization. The direct cross-linking of antibody with the $\mathrm{AS} @ \mathrm{Fe}_{3} \mathrm{O}_{4}$ MNPs was achieved through activation with a bifunctional linker, suberic acid bis( $N$-hydroxysuccinimide) ester (DSS), followed by incubation with the H5N2-specific monoclonal antibodies [41]. Compared with conventional approaches using protein $G$ or protein A for antibody immobilization, direct conjugation was chosen to avoid non-specific association arising from protein A-conjugated MNPs. Because of the presence of other abundant non-antigenic proteins in the allantoic fluid, we noted that proper surface blocking of the MNPs was essential to avoid nonspecific interactions, which seriously compete with specific nanoprobevirus recognition. Thus, further surface capping with an optimized concentration of methoxy-terminated ethylene-glycol amine (MEGA) was conducted to give the desired antibody-conjugated MNPs (designated as $\left.\mathrm{Ab}_{\mathrm{H} 5 \mathrm{~N} 2} @ \mathrm{Fe}_{3} \mathrm{O}_{4} \mathrm{MNPs}\right)$. The MEGA-capped $\mathrm{Ab}_{\mathrm{H} 5 \mathrm{~N} 2} @-$ $\mathrm{Fe}_{3} \mathrm{O}_{4}$ MNPs were washed with phosphate buffered saline (PBS, pH 7.4) and stored at $4^{\circ} \mathrm{C}$ for months without loss of activity.

The synthesized $\mathrm{AS} @ \mathrm{Fe}_{3} \mathrm{O}_{4}$ MNPs exhibited a spherical shape with an average diameter of $\sim 90 \pm 30 \mathrm{~nm}$, as seen in transmission electron microscopy (Figure 2A). The spinel structure of $\mathrm{AS} @ \mathrm{Fe}_{3} \mathrm{O}_{4} \mathrm{MNP}$ was revealed by powder X-ray diffraction (Figure $2 \mathrm{~B}$ ), which showed

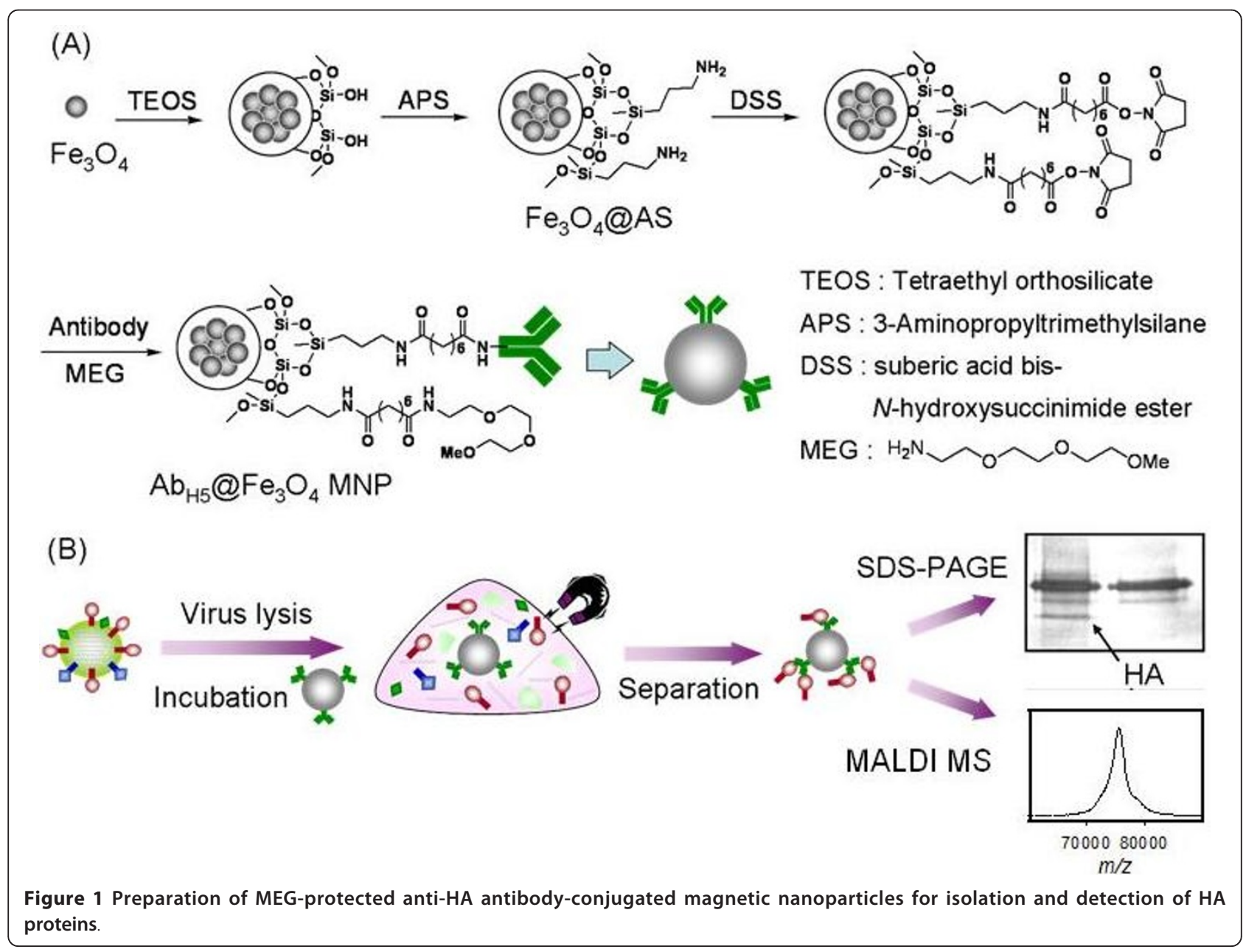



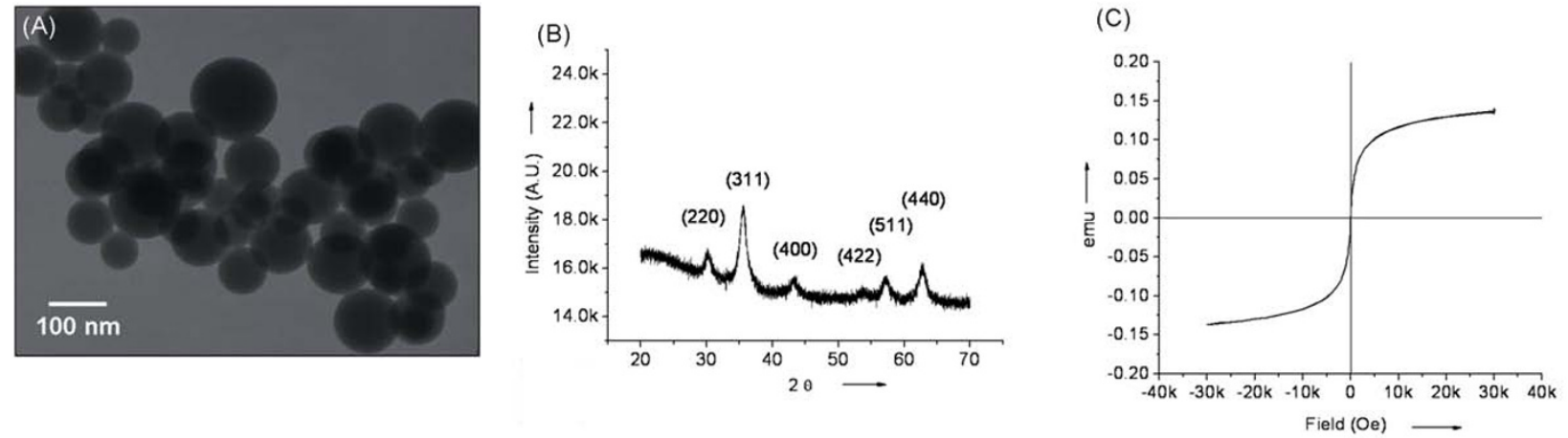

Figure 2 Characterization of the aminosilane-coated iron oxide magnetic nanoparticles $\mathrm{AS}_{0} \mathrm{Fe}_{3} \mathrm{O}_{4} \mathrm{MNP}$. A transmission electron microscopy image of $\mathrm{AS}_{0} \mathrm{Fe}_{3} \mathrm{O}_{4} \mathrm{MNP}(\mathrm{A})$, structural characterization by powder X-Ray diffraction spectroscopy (B), and magnetization characterization by superconducting quantum interference device magnetometer (C).

the characteristic pattern of diffraction peaks at (220), (311), (400), (422), (511) and (440) [42]. The AS@ $\mathrm{Fe}_{3} \mathrm{O}_{4}$ MNP was superparamagnetic at room temperature (Figure $2 \mathrm{C}$ ), as evidence by its hysteresis loop in superconducting quantum interference device magnetometer (SQUID) (i.e., the magnetization reached saturation in an external magnetic field, but the magnetic character diminished in the absence of an external magnetic field). The unique superparamagnetic property of AS@Fe $\mathrm{O}_{4}$ MNPs allowed easy magnetic separation from a complex mixture during synthesis or incubation.

\section{- Extraction of HA proteins by antibody-conjugated} magnetic nanoparticles and on-bead MALDI-MS analysis Our strategy for isolation and identification of HA proteins by $\mathrm{Ab}_{\mathrm{H} 5 \mathrm{~N} 2} @ \mathrm{Fe}_{3} \mathrm{O}_{4} \mathrm{MNP}$ is depicted in Figure 1B. Briefly, the $\mathrm{Ab}_{\mathrm{H} 5 \mathrm{~N} 2} @ \mathrm{Fe}_{3} \mathrm{O}_{4}$ MNPs were incubated with virus lysate in a chosen buffer. After incubation, the newly formed complexes containing $\mathrm{Ab}_{\mathrm{H} 5 \mathrm{~N} 2} @ \mathrm{Fe}_{3} \mathrm{O}_{4}$ MNPs and extracted HA (designated as HA-MNP complexes) were readily isolated by applying a magnet. The nonspecifically bound proteins were washed away, and the HA-MNP complexes were directly analyzed by either SDS-PAGE or MALDI-TOF MS. It was noted that both assays could be performed in an efficient manner without commonly required elution and desalting; our method thus reduced the time required for assay.

It was also noted that the incubation buffer was crucial to this experiment. Virus lysate in allantoic fluid has a complex composition, containing not only the H5N2 virus, but also other proteins abundant in the culture medium. Non-specific adsorption from these abundant proteins often interferes with immunoassays. Furthermore, HA is a trimeric transmembrane protein; thus detergent or salts are required to properly solubilize the hydrophobic protein and to avoid protein-protein aggregation. The effect of using different buffers on the specificity of affinity extraction was therefore evaluated. RIPA buffer, which is commonly used as a lysis buffer for immunoprecipitation assays, showed the best removal of abundant proteins capable of nonspecific interactions with $\mathrm{Ab}_{\mathrm{H} 5 \mathrm{~N} 2} @ \mathrm{Fe}_{3} \mathrm{O}_{4}$ MNPs. Consequently,

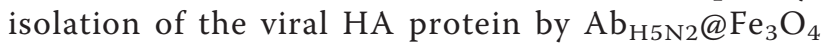
MNPs was more efficient in RIPA buffer than in water or PBS buffer.

MALDI-MS can be combined with a biologically active probe to rapidly and specifically detect proteins of interest. To explore the capability of on-MNP readout by MALDI-MS, a protein pool mimicking a complex biological medium was prepared in $60 \mu \mathrm{L}$ of PBS comprising various amounts of the recombinant HA protein of antigenic $\mathrm{H} 5$ type (200 ng, $100 \mathrm{ng}$ and $50 \mathrm{ng}$ ) and a significant excess of other "nonantigenic" proteins such as transferrin $(5 \mu \mathrm{g})$, fetuin $(5 \mu \mathrm{g})$ and ribonuclease $(1$ $\mu \mathrm{g})$. The abundance of the HA protein $(1.8-0.5 \%, \mathrm{w} / \mathrm{w})$ was purposely low to test the extraction efficiency of the $\mathrm{Ab}_{\mathrm{H} 5 \mathrm{~N} 2} @ \mathrm{Fe}_{3} \mathrm{O}_{4}$ MNPs. After enrichment of HA proteins, the HA-MNP complex was mixed with sinapinic acid (SA), a MALDI matrix, and directly subjected to MALDI-MS analysis.

Although the antibody-antigen complexes have strong interactions with dissociation constants $\left(K_{\mathrm{d}}\right)$ ranging from $10^{-7}$ to $10^{-11} \mathrm{M}$, most antibody-antigen complexes can still be dissociated at extreme $\mathrm{pH}$ (i.e., $\mathrm{pH}<2$ or $\mathrm{pH}>12)$. The SA matrix solution used for MALDI-MS analysis has a low $\mathrm{pH}(<2)$ and thus may directly elute the antigen bound to the antibody-conjugated MNPs on the MALDI sample plate.

Prior to affinity extraction (Figure 3A), the MALDI spectrum of the protein mixture was complex and the targeted HA was not observed due to its low abundance and ion suppression. After affinity extraction (Figure 3B), two distinct signals appeared at $m / z 75238$ and $37607 \mathrm{Da}$, which were derived from the glycosylated HA 


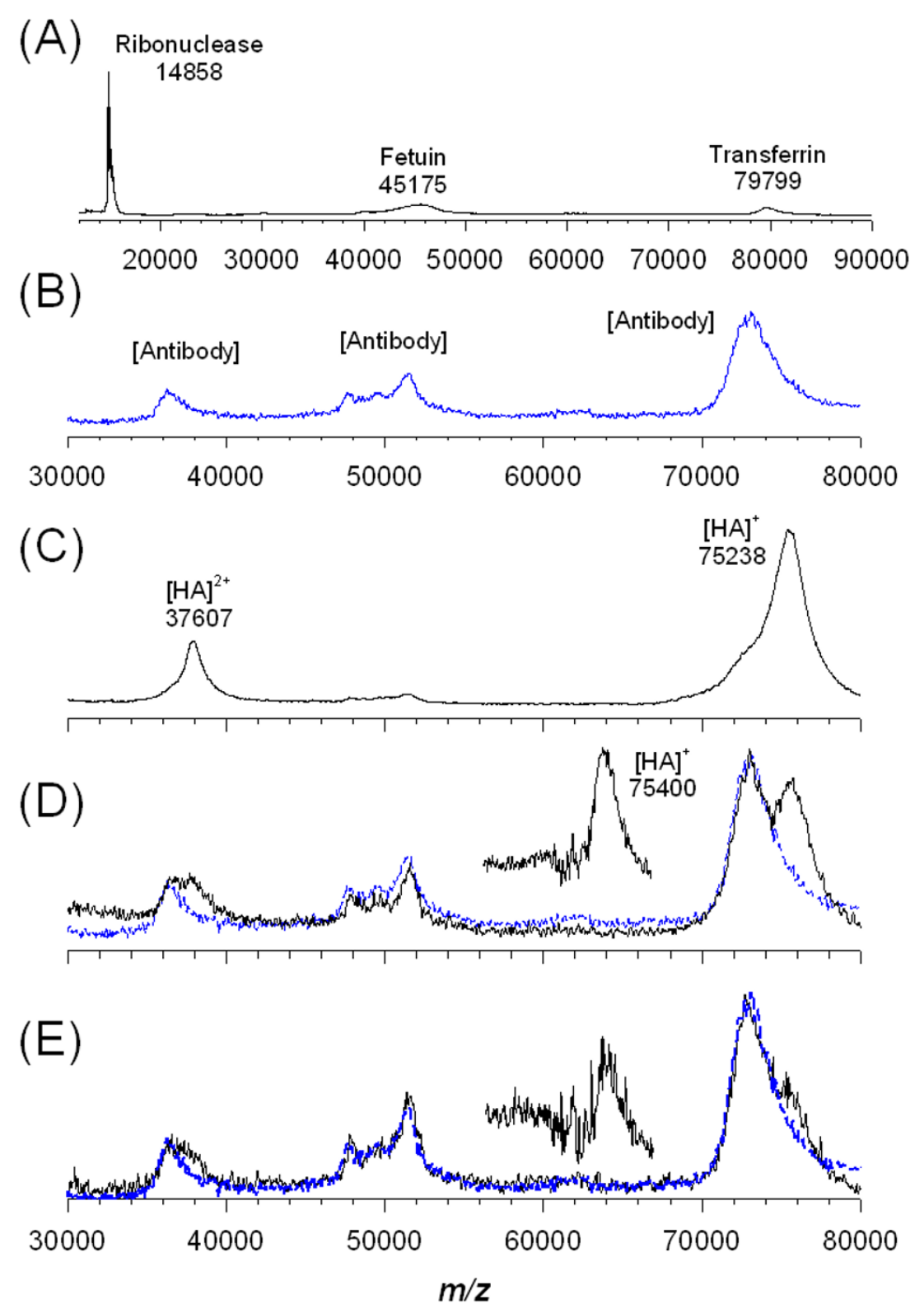

Figure 3 Detection sensitivity of $\mathrm{HA}$ protein ( $\mathrm{H} 5$ type) after extraction by $\mathrm{Ab}_{\mathrm{H}_{5} \mathrm{~N} 2} @ \mathrm{Fe}_{3} \mathrm{O}_{4}$ MNP. MALDI mass spectra of (A) protein solution $(60 \mu \mathrm{L})$ containing HA (200 ng), ribonuclease $(1 \mathrm{mg})$, fetuin $(5 \mathrm{mg})$ and transferrin $(5 \mathrm{mg})$; (B) background peaks from antibody; (C) extraction by $\mathrm{Ab}_{\mathrm{H} 5 \mathrm{~N} 2} @ \mathrm{Fe}_{3} \mathrm{O}_{4}$ MNP (HA signals at approximate $75 \mathrm{kDa}$ and $37 \mathrm{kDa}$, corresponding to singly and doubly charged ions); (D) extraction from a protein solution $(60 \mu \mathrm{L})$ containing HA (100 ng), ribonuclease (1 mg), fetuin $(5 \mathrm{mg})$ and transferrin $(5 \mathrm{mg})$ by $\mathrm{Ab}_{\mathrm{H} 5 \mathrm{~N} 2} @ \mathrm{Fe}_{3} \mathrm{O}_{4} \mathrm{MNP}$; and $(\mathrm{E})$

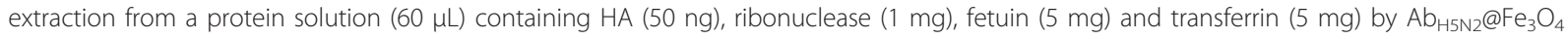
MNP. The arrow indicates the experimental $\mathrm{m} / \mathrm{z}$ of HA. The blue dotted line indicates the antibody. The HA signals after subtraction of the antibody signals are shown in the insets of (D) and (E).

protein with one and two charges $\left([\mathrm{M}+\mathrm{H}]^{+}\right.$and $[\mathrm{M}+$ $2 \mathrm{H}]^{2+}$, respectively) [25]. The characteristic broad peak shape of the glycosylated protein [43-45] could not be resolved under the mass resolution of our instrument. The shift of several $\mathrm{kDa}$ compared with the theoretical molecular weight of HA (theoretical average mass $\approx 64$ kDa) [43-45] might be attributable to the extensive glycosylation of HA [25]. When the solution containing less HA (100 ng) was analyzed, the signal intensity significantly decreased and partially overlapped with the antibody signals to form a doublet mass peak (Figure 3D). After subtraction of the mass spectrum of the antibody (Figure $3 \mathrm{~B}$ ), the mass peak occurring at $\mathrm{m} / \mathrm{z}$ $\sim 75400$ Da clearly showed the presence of HA protein. 
The affinity extraction of HA protein from a complex mixture was very efficient using the antibody-conjugated MNPs, as even a minute amount (50 ng) of HA protein was visible (Figure 3E). Assuming full recovery of all the HA protein (50 ng) present in the solution, the absolute detection limit was estimated to be $0.7 \mathrm{pmol}(9 \mathrm{nM})$.

To evaluate the efficiency of our detection method, we investigated the effect of incubation time on HA protein and antibody-conjugated MNP recognition. After incubation of antibody-conjugated MNPs with HA containing solution, the amount of remaining $\mathrm{HA}$ was concentrated and measured by MALDI-MS. The time course of such affinity extraction indicated that $>99 \%$ of HA protein in solution was captured by MNPs within 1 min (Figure 4). Thus, using antibody-conjugated MNPs for rapid and specific extraction, followed by direct mass spectrometric analysis for ambiguous readout, provides an efficient and accurate assay for HA protein.

\section{- Isolation of HA proteins from a virus sample for electrophoresis and mass spectrometric analyses}

The affinity extraction of $\mathrm{H} 5 \mathrm{~N} 2$ viruses in allantoic fluid was also realized using $\mathrm{Ab}_{\mathrm{H} 5 \mathrm{~N} 2} @ \mathrm{Fe}_{3} \mathrm{O}_{4}$ MNPs. As shown in SDS-PAGE analysis, without concentration of the virus lysate from allantoic fluid, only the abundant protein NP was observed in $\mathrm{H} 5 \mathrm{~N} 2$ virus (Figure $5 \mathrm{~A}$, lane 1). Using $2 \times$ RIPA buffer, the $\mathrm{Ab}_{\mathrm{H}_{5 \mathrm{~N}} 2} @ \mathrm{Fe}_{3} \mathrm{O}_{4}$ MNPs selectively isolated the viral HA protein from allantoic fluid (Figure 5A, lanes 2 and 3). As influenza HA protein $\left(\mathrm{H}_{0}\right)$ is composed of two disulfide-linked polypeptides, $\mathrm{HA}_{1}$ and $\mathrm{HA}_{2}$, the use of a reducing reagent, like $\beta$-mercaptoethanol, in SDS-PAGE analysis will dissociate the HA protein into the two subunits $\mathrm{HA}_{1}$ and $\mathrm{HA}_{2}$. After treatment with $\beta$-mercaptoethanol, an electrophoresis band occurring at $\sim 45-50 \mathrm{kDa}$ was attributable to the glycosylated $\mathrm{HA}_{1}$ protein (Figure $5 \mathrm{~A}$, lanes 2 and 3) [25,43-45]. The band with molecular mass in the range of 50-60 $\mathrm{kDa}$ was ascribed to the proteins of antibody from $\mathrm{Ab}_{\mathrm{H} 5 \mathrm{~N} 2} @ \mathrm{Fe}_{3} \mathrm{O}_{4}$ MNPs (Figure $5 \mathrm{~A}$, lane 5). As a negative control, we also synthesized MEG@ $\mathrm{Fe}_{3} \mathrm{O}_{4} \quad$ MNPs from aminosilane coated $\mathrm{AS} @ \mathrm{Fe}_{3} \mathrm{O}_{4}$ MNPs and MEGA without antibody conjugation. As expected, SDS-PAGE analysis showed that no viral protein was trapped by $\mathrm{MEG@Fe} \mathrm{O}_{4} \mathrm{MNPs}$. These results demonstrated the low background and the lack of false positives (Figure 5A, lane 4) in the presented method.

To evaluate the assay sensitivity, $\mathrm{Ab}_{\mathrm{H} 5 \mathrm{~N} 2} @ \mathrm{Fe}_{3} \mathrm{O}_{4}$ MNPs $(10 \mu \mathrm{g})$ were incubated with different amounts (0.05-1 $\mu \mathrm{L})$ of the 1000 -fold diluted $\mathrm{H} 5 \mathrm{~N} 2$ virus lysate $\left(\sim 10^{7.8} \mathrm{EID}_{50} / \mathrm{mL}\right.$, Figure $\left.5 \mathrm{~B}\right)$. As low as $0.1 \mu \mathrm{L}$ of virus lysate, corresponding to $\sim 10^{3.8} \mathrm{EID}_{50}$ of $\mathrm{H} 5 \mathrm{~N} 2$ viruses, was detected by SDS-PAGE using silver staining for visualization (Figure 5B, line 4).

To further confirm the identity of the captured protein, the electrophoresis band at $\sim 45 \mathrm{kDa}$ was digested with trypsin and subjected to LC-MS/MS analysis. Database searching with the Mascot engine confidently identified eight peptide sequences corresponding to the viral $\mathrm{HA}_{1}$ protein (Figure $6 \mathrm{~B}$ ). An example MS/MS spectrum is shown in Figure 6A for the peptide SELEYGNCNTR

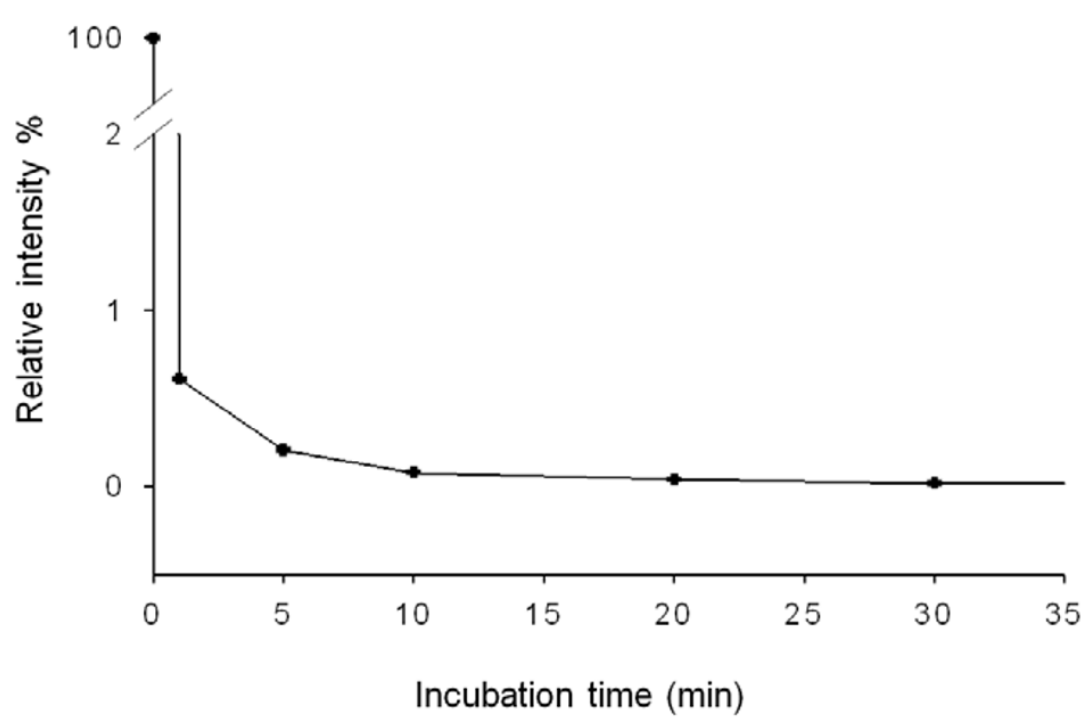

Figure 4 Kinetic effect on $\mathrm{HA}$ enrichment using $\mathrm{Ab}_{\mathrm{H}_{5} \mathbf{N} 2} @ \mathrm{Fe}_{3} \mathrm{O}_{4}$ MNP. To investigate the time course of HA extraction, supernatant was sampled from a $60-\mathrm{mL}$ reaction after different incubation times (1-30 min). HA remaining in the supernatant was vacuum dried and quantified by MALDI MS peak intensities. 



Figure $5 \mathrm{HA}$ purification performance by $\mathrm{Ab}_{\mathrm{H}_{5 N} 2} @ \mathrm{Fe}_{3} \mathrm{O}_{4}$. (A) Lane 1: $\mathrm{H} 5 \mathrm{~N} 2$ virus (200 ng) prepared from allantoic fluid; Lane 2: isolation of HA protein after incubation of $\mathrm{Ab}_{\mathrm{H} 5 \mathrm{~N} 2} @ \mathrm{Fe}_{3} \mathrm{O}_{4} \mathrm{MNP}$ with $1 \mu \mathrm{g}$ of $\mathrm{H} 5 \mathrm{~N} 2$ virus lysate; Lane 3: isolation of HA protein after incubation of $\mathrm{Ab}_{\mathrm{H} 5 \mathrm{~N} 2} @ \mathrm{Fe}_{3} \mathrm{O}_{4}$ MNP with 200 ng of H5N2 virus lysate; Lane 4: control experiment using MEG@MNP for incubation with 200 ng of H5N2 virus lysate; Lane 5: $\mathrm{Ab}_{\mathrm{H} 5 \mathrm{~N} 2} @ \mathrm{Fe}_{3} \mathrm{O}_{4}$ MNP only. The antibody signals arise from dissociation of Ab $\mathrm{H}_{\mathrm{H} N 2}$ during SDS-PAGE analysis. (B) Purification efficiency of $\mathrm{Ab}_{\mathrm{H} 5 \mathrm{~N} 2} @ \mathrm{Fe}_{3} \mathrm{O}_{4}$ MNP. SDS-PAGE patterns of Ab $\mathrm{H}_{5 \mathrm{~N} 2} @ \mathrm{Fe}_{3} \mathrm{O}_{4}$ MNP before and after incubation of $\mathrm{Ab}_{\mathrm{H}_{5} \mathrm{~N}_{2} @ \mathrm{Fe}} \mathrm{O}_{4} \mathrm{MNP}_{4}$ with H5N2 virus lysate in $2 \times$ RIPA buffer. Lane 1: H5N2 virus; Lanes 2-5: incubation of $\mathrm{Ab}_{\mathrm{H} 5 \mathrm{~N} 2} @ \mathrm{Fe}_{3} \mathrm{O}_{4} \mathrm{MNP}(2 \mu \mathrm{L})$ with 1, 0.5, 0.1 and $0.01 \mu \mathrm{L}$ of H5N2 virus, respectively; Lanes 6-9: supernatant of Lanes 2-5.

at $m / z$ 1341.4837, which corresponds to amino acids 282-292 of the HA protein from the H5N2 virus.

\section{- Differentiation of influenza virus subtypes}

Finally, we evaluated whether the high specificity of $\mathrm{Ab}_{\mathrm{H} 5 \mathrm{~N} 2} @ \mathrm{Fe}_{3} \mathrm{O}_{4}$ MNP could be used to unambiguously differentiate virus subtypes. Besides the H5N2 virus (A/ Duck/Taiwan/3233/04), three recombinant $\mathrm{H} 5 \mathrm{~N} 1$ viruses (RG5, RG23, and NIBRG14) were investigated. All of these influenza viruses belong to the $\mathrm{H} 5$ category of influenza A, but it was expected that the $\mathrm{Ab}_{\mathrm{H} 5 \mathrm{~N} 2} @-$ $\mathrm{Fe}_{3} \mathrm{O}_{4}$ MNP incorporating the monoclonal antibody specifically against the $\mathrm{H} 5 \mathrm{~N} 2$ virus would not have crossreactivity with the $\mathrm{H} 5 \mathrm{~N} 1$ virus subtype. To validate such detection specificity, the lysates of $\mathrm{H} 5 \mathrm{~N} 2$ and $\mathrm{H} 5 \mathrm{~N} 1$ viruses were incubated separately with $\mathrm{Ab}_{\mathrm{H} 5 \mathrm{~N} 2} @ \mathrm{Fe}_{3} \mathrm{O}_{4}$ MNPs in $2 \times$ RIPA buffer at $25^{\circ} \mathrm{C}$. After magnetic separation, the pellet was washed with $1 \times$ RIPA buffer and subjected to MALDI-MS analysis. As shown in Figure 7A, the MALDI mass spectrum obtained from the on-MNP detection of extracted H5N2 virus (A/Duck/ Taiwan/3233/04) revealed strong signals from viral proteins bound on $\mathrm{Ab}_{\mathrm{H} 5 \mathrm{~N} 2} @ \mathrm{Fe}_{3} \mathrm{O}_{4}$ MNP. After subtraction of the antibody spectrum shown in Figure $7 \mathrm{C}$, the mass spectrum clearly showed signals for glycosylated HA together with the relatively abundant NP $(56002 \pm 10$ $\mathrm{Da})$ and M1 $(28000 \pm 10 \mathrm{Da})$ proteins from H5N2 virus (Figure 7B). Gratifyingly, none of the recombinant $\mathrm{H} 5 \mathrm{~N} 1$ viruses were trapped by the $\mathrm{Ab}_{\mathrm{H} 5 \mathrm{~N} 2} @ \mathrm{Fe}_{3} \mathrm{O}_{4}$ MNP. A representative mass spectrum obtained from a screening of H5N1 (RG5) is shown in Figure 7D, and only antibody signals were observed, confirming highly specific affinity isolation of $\mathrm{H} 5 \mathrm{~N} 2$. These data demonstrated the promising application of $\mathrm{Ab}_{\mathrm{H} 5 \mathrm{~N} 2} @ \mathrm{Fe}_{3} \mathrm{O}_{4}$ MNPs to distinguish different subtypes in influenza virus surveillance.

\section{Conclusions}

We have demonstrated a facile method for the detection of H5N2 influenza virus using aminosilane coated iron oxide nanoparticles with surface functionalization of monoclonal antibodies specific to the HA protein in H5N2. Through simple magnetic separation, the $\mathrm{Ab}_{\mathrm{H} 5 \mathrm{~N} 2} @ \mathrm{Fe}_{3} \mathrm{O}_{4}$ MNPs showed effective isolation of $\mathrm{H} 5 \mathrm{~N} 2$ viruses from lysate for direct MALDI-TOF MS readout without the need for a tedious elution step. The 


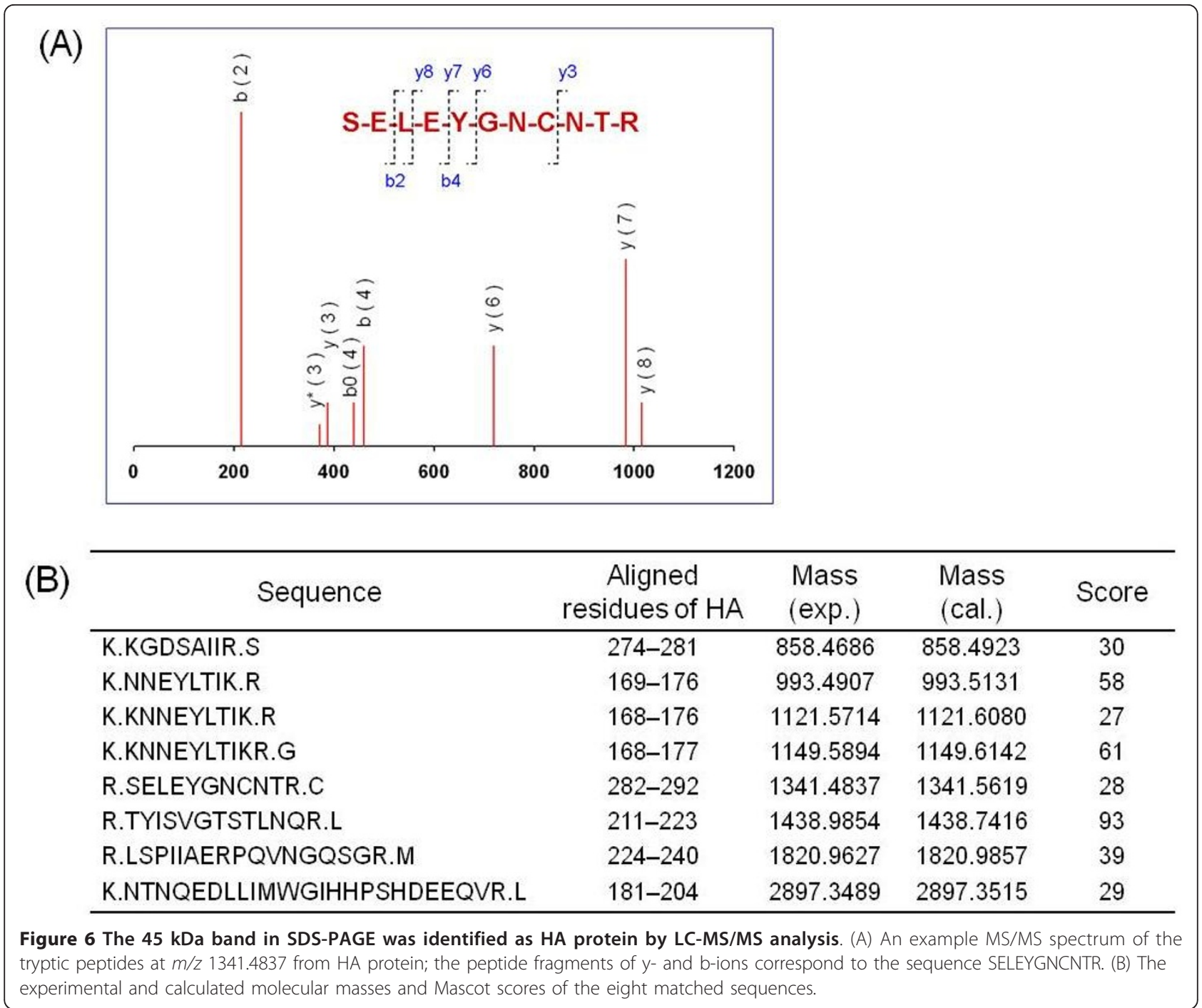

detection limit was in the range of $\sim 10^{4} \mathrm{EID}_{50}$ by SDSPAGE or $\sim 10^{3}$ EID $_{50}$ by MALDI-TOF MS. Our study demonstrated that the combined use of antibody-MNPs and MALDI-MS was suitable for sensitive detection of influenza viruses. Although the direct quantitative comparison of our method with other previously reported diagnostic methods is difficult because each method characterizes a specific property of the virus under various conditions, our present method appears to provide comparable or better sensitivity in the detection of influenza virus than commercially available kits $[8,10]$. These kits have a limit of detection in the range of $10^{4.5}-10^{5.5}$ $\mathrm{TCID}_{50}$ or $10^{4.7} \mathrm{ELD}_{50}$. Therefore, the method presented here can be utilized for the rapid screening of virus subtypes. The overall workflow of our method for influenza virus detection including virus lysis, magnetic separation and MALDI-TOF MS measurement can be routinely completed in one hour. We also demonstrated, for the first time, that the nanoprobe-based detection unambiguously differentiated the $\mathrm{H} 5 \mathrm{~N} 2$ virus from other closely related antigenic subtypes of (recombinant) H5N1 viruses in a highly specific manner.

With the automatic readout of MALDI-TOF MS, our method has the potential for integration into highthroughput virus assays, suggesting a promising application in early and accurate diagnosis of influenza viruses. Given the increasing use of virus screening assays, our current assay offers a flexible design for immobilization of other virus-specific molecular probes on a nanoparticle surface for diverse applications.

\section{Methods}

\section{Materials}

All of the chemicals were of reagent grade unless indicated otherwise. Ferrous chloride tetrahydrate $\left(\mathrm{FeCl}_{2} \cdot 4 \mathrm{H}_{2} \mathrm{O}\right)$, ferric chloride $\left(\mathrm{FeCl}_{3}\right)$, tetraethyl 


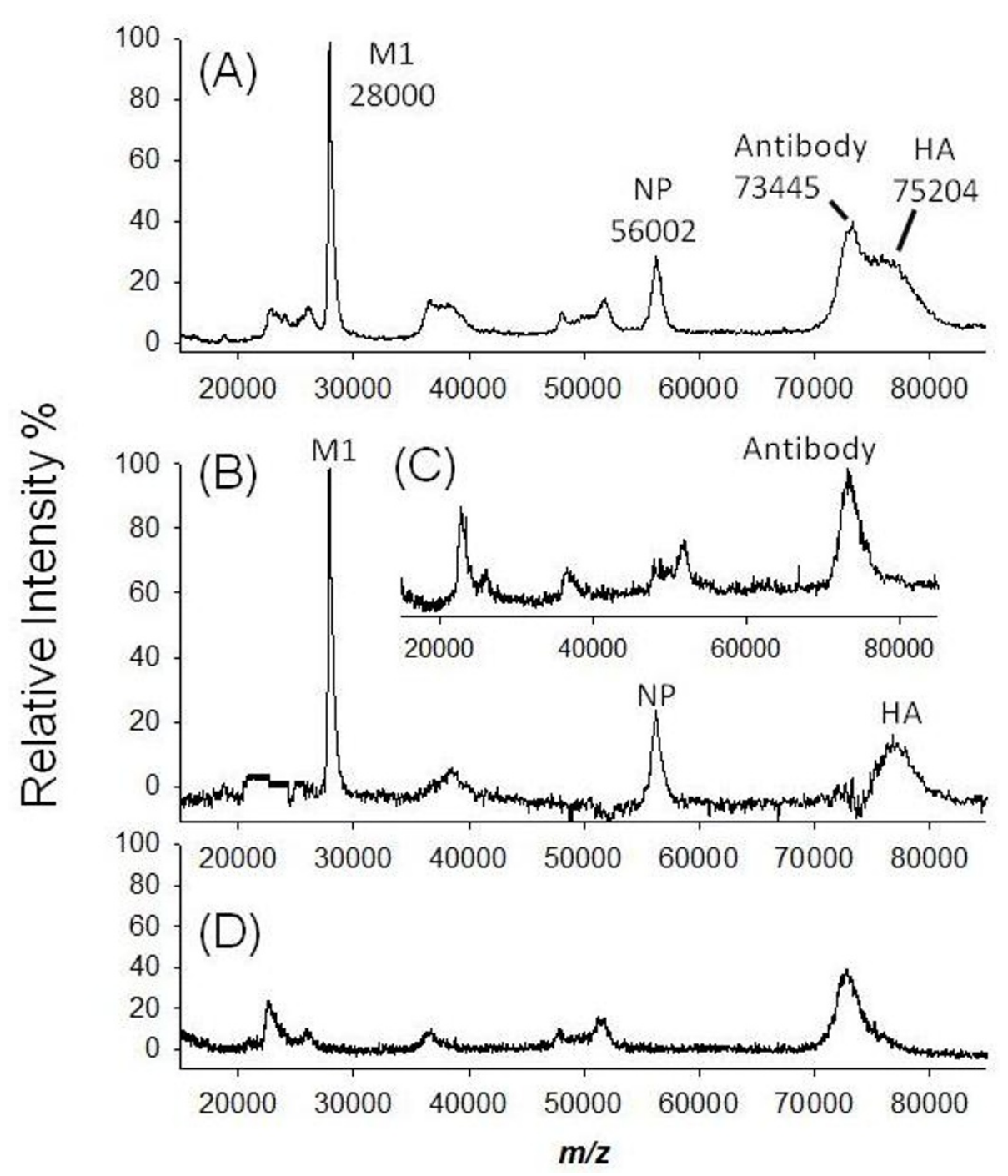

Figure 7 Virus screening by incubation of $\mathbf{A b}_{\mathrm{H}_{5} \mathrm{~N} 2} @ \mathrm{Fe}_{3} \mathrm{O}_{4}$ MNP with the lysate of different viruses. The examined viruses (40 $\left.\mu \mathrm{L}\right)$ include H5N2 (A/Duck/Taiwan/3233/04) and recombinant H5N1 (RG5, RG23, and NIBRG14). After incubation, only the H5N2 subtype was enriched. (A) HA, NP and M1 proteins were observed in the MALDI mass spectrum; (B) after subtracting the antibody signals (inset C), the HA, NP and M1 signals were clearly observed with good signal-to-noise ratio. For other viruses, only antibody signals were observed. A representative mass spectrum obtained from screening of RG5 is shown in (D).

orthosilicate (TEOS), 3-aminopropyltrimethoxysilane (APS), 1-propanol, ammonia solution (28\%), and dimethyl sulfide were purchased from Acros. Suberic acid bis- $N$-hydroxysuccinimide ester (DSS), 2-bromoethylamine hydrobromide (BEI), sodium carbonate, silver nitrate, $\alpha$-cyano-4-hydroxycinnamic acid (CHCA), and sinapinic acid (SA) were purchased from SigmaAldrich. Formalin, methanol, acetonitrile (HPLC grade), and trifluoroacetic acid (TFA) were purchased from Merck. Acetic acid and sodium thiosulfate were purchased from J. T. Baker. All the chemicals were used as received without further purification. A homemade magnet was used in the separation of magnetic nanoparticles.
The HA proteins of $\mathrm{H} 5$ type were prepared using the H5 consensus sequence previously described [46]. The 1 $\times$ PBS buffer $(\mathrm{pH} 7.4, \mathrm{GIBCO})$ contained $\mathrm{NaCl}(137$ $\mathrm{mM}), \mathrm{KCl}(2.7 \mathrm{mM}), \mathrm{KH}_{2} \mathrm{PO}_{4}(1.5 \mathrm{mM})$ and $\mathrm{Na}_{2} \mathrm{HPO}_{4}$ $(8.1 \mathrm{mM})$. The $1 \times$ RIPA buffer $(\mathrm{pH} 8.0)$ contained Tris$\mathrm{HCl}$ (50 mM, Amersham Bioscience), $\mathrm{NaCl}$ (150 mM), NP-40 (1\%, Calbiochem), sodium deoxycholate $(0.5 \%$, Sigma) and sodium dodecyl sulfate (0.1\%, USB). The $2 \times$ RIPA buffer ( $\mathrm{pH} 8.0)$ contained Tris- $\mathrm{HCl}(50 \mathrm{mM})$, $\mathrm{NaCl}(150 \mathrm{mM}), \mathrm{NP}-40$ (2\%), sodium deoxycholate (1\%) and sodium dodecyl sulfate $(0.1 \%)$. The TEN buffer $(\mathrm{pH}$ 7.5) contained Tris- $\mathrm{HCl}(50 \mathrm{mM}, \mathrm{pH} 7.5)$, EDTA (pH 8.0, $1.3 \mathrm{mM})$ and $\mathrm{NaCl}(100 \mathrm{mM})$. 


\section{Instruments}

Transmission electron microscopy (TEM) images were obtained on a Hitachi H-7100 Transmission Electron Microscope. Powder X-Ray Diffraction (XRD) was recorded by PANalytical X' Pert PRO. The magnetic effect was measured on a superconducting quantum interference device magnetometer (SQUID, Quantum Design MPMS7). LC-MS/MS spectra were recorded on a Waters Q-TOF ${ }^{\mathrm{TM}}$ Premier mass spectrometer (Waters Corp, Milford, MA). MALDI-TOF MS analyses were performed using an Applied Biosystems 4800 mass spectrometer (Applied Biosystems, Foster City, USA) equipped with a Nd-YAG laser (355 nm).

\section{- Preparation of virus}

The supernatant $(0.2 \mathrm{~mL} / \mathrm{egg})$ of $\mathrm{H} 5 \mathrm{~N} 2$ influenza virus A/duck/Yunlin/04 (H5N2) was inoculated to the allantoic cavity of 9 to 11-day-old specific pathogen-free (SPF) embryonated hens' eggs, which were then cultivated in an incubator. The eggs that died within $24 \mathrm{~h}$ were discarded. Other eggs were incubated at $4^{\circ} \mathrm{C}$ for another $4 \mathrm{~h}$ to contract blood vessels. The allantoic fluid was then collected by needle and stored at $-80^{\circ} \mathrm{C}$.

To separate the cell lysate, the allantoic fluid was frozen and thawed several times to rupture the cells. The solution was subjected to centrifugation $(3000 \mathrm{rpm}$, Centrifuge 5804R, Eppendorf, Germany) at $4^{\circ} \mathrm{C}$ for 15 min. The supernatant was treated with $1 \% \mathrm{BEI}$ at $37^{\circ} \mathrm{C}$ for $18 \mathrm{~h}$ to inactivate the virus. After centrifugation (70, $000 \times g$, Avanti J-25 Centrifuge, Beckman) at $4^{\circ} \mathrm{C}$, the virus pellets were collected, dissolved in TEN buffer, and stored overnight at $4{ }^{\circ} \mathrm{C}$. The virus was then separated by centrifugation (50, $000 \mathrm{rpm}$, Optima MAX-E Ultracentrifuge, Beckman) in a sucrose gradient (20$50 \%)$ at $4^{\circ} \mathrm{C}$ for $2 \mathrm{~h}$. The concentrated H5N2 virus solution in TEN buffer was estimated to have an $\operatorname{EID}_{50}(50 \%$ egg infectious dose) value of about $10^{10.8}$ per $\mathrm{mL}$, corresponding to $\sim 10^{11}$ particles $/ \mathrm{mL}$ estimated using the TEM-imaging of a mixture of viruses and a known concentration of polystyrene latex beads (137 $\mathrm{nm}$ in diameter) [47].

The recombinant $\mathrm{H} 5 \mathrm{~N} 1$ viruses RG5 (A/Anhui/1/ 2005), RG23 (A/turkey/Turkey/01/2003) and NIBRG14 (A/Vietnam/1194/2004) were obtained from Dr. JiaTsrong Jan (The Genomics Research Center, Academia Sinica) [46]. The $\mathrm{TCID}_{50}$ (50\% tissue culture infectious dose) on Madin-Darby canine kidney (MDCK) cells was estimated to be around $3 \times 10^{6}$ (RG5), $1 \times 10^{5}$ (RG23), and $3 \times 10^{6}$ (NIBRG14) per $\mathrm{mL}$, respectively, according to the Reed-Muench method [48].

\section{- Preparation of antibody}

The monoclonal antibodies against A/duck/Yunlin/04 (H5N2) virus were purchased from LTK BioLaboratories (Taipei, Taiwan) and purified on an immunoglobin affinity column. Briefly, a protein A HiTrap affinity column
(Pharmacia biotech, Orsay, France) was activated with binding buffer $(20 \mathrm{mM}$ sodium phosphate buffer, $\mathrm{pH}$ 7.0). The ascites $(1 \mathrm{~mL})$ were mixed with Tris- $\mathrm{HCl}(200$ $\mu \mathrm{L}$ of $1 \mathrm{M}$ solution, $\mathrm{pH} 9.0$ ) and applied to the affinity column. After the turbid impurities were washed off with binding buffer $(10 \times$ column volume $)$, a striping buffer $(700 \mu \mathrm{L}$ of $0.1 \mathrm{M}$ citric acid, $\mathrm{pH}$ 3.0) was applied to elute the antibodies. The collected antibody solution was then dialyzed in $1 \mathrm{~L}$ of PBS buffer $(0.1 \mathrm{M})$ and stored at $-20^{\circ} \mathrm{C}$. The content of antibody protein $(3 \times$ $10^{3} \mu \mathrm{g} / \mathrm{mL}$ ) was measured by the Bradford method [49].

\section{- Preparation of aminosilane coated iron oxide magnetic nanoparticles}

Iron oxide nanoparticles $\left(\mathrm{Fe}_{3} \mathrm{O}_{4}\right)$ were synthesized using $\mathrm{FeCl}_{2}$ and $\mathrm{FeCl}_{3}$ under basic conditions according to the previously reported method [40]. The freshly prepared $\mathrm{Fe}_{3} \mathrm{O}_{4}$ nanoparticles (30 mg) were suspended in 1-propanol $(80 \mathrm{~mL})$ and sonicated for $40 \mathrm{~min}$ at room temperature. Next, $\mathrm{NH}_{4} \mathrm{OH}(28 \% \mathrm{w} / \mathrm{w}, 8.94 \mathrm{~mL}), \mathrm{ddH}_{2} \mathrm{O}$ $(7.5 \mathrm{~mL})$, and TEOS $(0.1 \mathrm{~mL})$ were slowly added to the above solution, and the mixture was stirred at $40^{\circ} \mathrm{C}$ for $2 \mathrm{~h}$. APS $(0.1 \mathrm{~mL})$ was injected into the solution and the mixture was stirred for another $1 \mathrm{~h}$. The blackish precipitates were collected with a magnet and washed with 1-propanol to give the aminosilane coated iron oxide magnetic nanoparticles ( $\mathrm{AS} @ \mathrm{Fe}_{3} \mathrm{O}_{4} \mathrm{MNP}$ ).

\section{- Synthesis of antibody conjugated magnetic nanoparticles}

AS@Fe $\mathrm{O}_{4}$ MNPs (0.5 mg) were suspended in DMSO $(125 \mu \mathrm{L})$ and sonicated for $30 \mathrm{~min}$ at room temperature. DSS (5 mg) was added to the solution and the mixture was stirred at room temperature for $1 \mathrm{~h}$. The precipitates were separated by magnet and washed with DMSO $(250 \mu \mathrm{L})$ three times. The antibody $(15 \mu \mathrm{L})$ was added at $4^{\circ} \mathrm{C}$. After $1 \mathrm{~h}$, a blocking reagent, 3, 6, 9trioxadecylamine (a methoxy-terminated ethylene glycol amine, MEGA, $35 \mu \mathrm{L}$ of $30 \mathrm{mM}$ solution in DMSO), was added to the mixture. The mixture was stirred for another $18 \mathrm{~h}$ at $4^{\circ} \mathrm{C}$, and the precipitates were collected by magnet. After washing with $\mathrm{PBS}$, the antibody conjugated nanoparticles $\left(\mathrm{Ab}_{\mathrm{H} 5 \mathrm{~N} 2} @ \mathrm{Fe}_{3} \mathrm{O}_{4} \mathrm{MNP}\right)$ were re-dissolved in PBS $(50 \mu \mathrm{L})$ and stored at $4^{\circ} \mathrm{C}$. By a similar procedure but without the addition of antibody, the ethylene glycol encapsulated nanoparticles MEGA@$\mathrm{Fe}_{3} \mathrm{O}_{4} \mathrm{MNP}$ were prepared and used as the control in experiments.

- Incubation of $\mathrm{Ab}_{\mathrm{H} 5 \mathrm{~N} 2} @ \mathrm{Fe}_{3} \mathrm{O}_{4} \mathrm{MNP}$ with viruses

Concentrated $\mathrm{H} 5 \mathrm{~N} 2$ virus solution $\left(2 \mu \mathrm{L}\right.$ of $1.03 \times 10^{3}$ $\mu \mathrm{g} / \mathrm{mL}$ in TEN buffer) was incubated with $2 \times$ RIPA buffer $(57 \mu \mathrm{L})$ at $25^{\circ} \mathrm{C}$ for $1 \mathrm{~h}$. An aliquot $(1 \mu \mathrm{L})$ of $\mathrm{Ab}_{\mathrm{H} 5 \mathrm{~N} 2} @ \mathrm{Fe}_{3} \mathrm{O}_{4} \mathrm{MNP}(0.5 \mathrm{mg}$ in $50 \mu \mathrm{L}$ of $1 \times \mathrm{PBS})$ was added to the virus solution and incubated for $30 \mathrm{~min}$. The HA-MNP complexes were then isolated by magnet and washed with $1 \times$ RIPA buffer for the subsequent SDS-PAGE and MALDI-TOF MS analyses. 


\section{- SDS-PAGE analysis of HA-nanoparticle conjugates}

The above-prepared HA-MNP complexes were resuspended in sample buffer containing $50 \mathrm{mM}$ Tris- $\mathrm{HCl}$ $(\mathrm{pH} 6.8)$, SDS $(1 \%, \mathrm{w} / \mathrm{v})$, glycerol $(10 \%, \mathrm{v} / \mathrm{v})$, bromophenol blue $(0.01 \%, \mathrm{w} / \mathrm{v})$, and $0.7 \mathrm{M} \beta$-mercaptoethanol, and then heated at $95^{\circ} \mathrm{C}$ for $5 \mathrm{~min}$. The sample was then separated on $10 \%$ SDS-PAGE gel in a running buffer containing Tris $(0.3 \%, \mathrm{w} / \mathrm{v})$, glycine $(1.2 \%, \mathrm{w} / \mathrm{v})$ and SDS $(0.1 \%, \mathrm{w} / \mathrm{v})$. Visualization of the protein bands was performed by silver staining. The SDS-PAGE was fixed with a solution containing $50 \%$ methanol, $12 \%$ acetic acid and $0.05 \%$ formalin for at least $2 \mathrm{~h}$. The gel was washed three times with $35 \%$ ethanol for $20 \mathrm{~min}$ and soaked in a sensitizer solution $(0.02 \%$ sodium thiosulfate) for $2 \mathrm{~min}$. The gel was washed three times with deionized water and then incubated with a staining buffer containing silver nitrate $(0.2 \%, \mathrm{w} / \mathrm{v})$ and formalin $(0.076 \%)$ in the dark for $20 \mathrm{~min}$. The gel was then washed twice with deionized water. The band images were developed in a $50 \mathrm{~mL}$ solution containing sodium carbonate $(6 \%, \mathrm{w} / \mathrm{v})$, sodium thiosulfate $(0.0004 \%, \mathrm{w} / \mathrm{v})$ and formalin $(0.05 \%)$. The silver reduction was processed for about 2 min until the expected intensity of protein was reached. Image development was terminated by treatment with a stop solution containing acetic acid $(12 \%)$ and methanol (50\%) for $5 \mathrm{~min}$, then stored at $4^{\circ} \mathrm{C}$ in $1 \%$ acetic acid.

\section{- Protein digestion and LC-MS/MS analysis}

After electrophoresis, the band at $\sim 45 \mathrm{kDa}$, corresponding to the $\mathrm{HA}_{1}$ protein, was taken from the SDS-PAGE gel and cut into small pieces $\left(1 \mathrm{~mm}^{3}\right)$. The gel slices were washed with $25 \mathrm{mM}$ ammonium bicarbonate and $50 \%$ acetonitrile, reduced with $10 \mathrm{mM}$ dithiothreitol, and then alkylated with $55 \mathrm{mM}$ iodoacetamide. Trypsin (protein/trypsin $=20: 1, \mathrm{~g} / \mathrm{g}$ ) was used to digest the protein by incubation for $12 \mathrm{~h}$ at $37^{\circ} \mathrm{C}$. The resulting peptides were extracted with acetonitrile/TFA $(50 \% / 0.1 \%)$ and then acetonitrile. The peptide solution was concentrated on a SpeedVac and reconstituted in $8 \mathrm{~L}$ of $0.1 \%$ TFA aqueous solution (buffer A).

For protein identification by LC-MS/MS, the digested peptides were injected into a capillary trap column (2 $\mathrm{cm} \times 180 \mu \mathrm{m})$ and separated on a BEH C18 column $(25$ $\mathrm{cm} \times 75 \mathrm{~mm} \times 1.7 \mathrm{~mm}$, Waters ACQUITY, Milford, MA). The column was maintained at $35^{\circ} \mathrm{C}$ and the bound peptides were eluted with a linear gradient of 0 $80 \%$ buffer $\mathrm{B} / \mathrm{A}$ (buffer $\mathrm{A}, 0.1 \%$ TFA in $\mathrm{H}_{2} \mathrm{O}$; buffer $\mathrm{B}$, $0.1 \%$ TFA in acetonitrile) for 80, 120, 180, 210 and 270 minutes. MS was operated in ESI positive $\mathrm{V}$ mode with a resolving power of 10,000. NanoLockSpray source was used for accurate mass measurement and the lock mass channel was sampled every 30 seconds. The mass spectrometer was calibrated with a synthetic human $\left[\mathrm{Glu}^{1}\right]$-Fibrinopeptide B solution $(1 \mathrm{pmol} / \mu \mathrm{L}$, from
Sigma-Aldrich) delivered through the NanoLockSpray source. Data acquisition was operated in the data directed analysis (DDA) mode. The method included a full MS scan ( $m / z$ 400-1600, 0.6 seconds) and three MS/MS scans $(m / z 100-1990,1.2$ seconds each scan) sequentially on the three most intense ions present in the full scan mass spectrum. The identification of peptide sequences was performed by database searching of MS/MS spectra using the Mascot algorithm (v2.1.0, Matrix Science, London, UK) against the NCBI database. The peak lists in the MS/MS spectra were extracted from Analyst QS 1.1 (Applied Biosystems) software with the default charge state set to $2+, 3+$, and $4+$. Search parameters for peptide and MS/MS mass tolerance were \pm 0.3 and $\pm 0.1 \mathrm{Da}$, respectively, with allowance for two missed cleavages from the trypsin digest and variable modifications of carbamidomethyl (Cys) and oxidation (Met). Peptides were considered confidently identified if their Mascot individual ion scores were higher than the Mascot identity scores $(p<0.05)$.

\section{- MALDI-TOF MS analysis}

The sample of $\mathrm{H} 5 \mathrm{~N} 2$ virus enriched by trapping with $\mathrm{Ab}_{\mathrm{H} 5 \mathrm{~N} 2} @ \mathrm{Fe}_{3} \mathrm{O}_{4}$ MNPs was mixed with fresh sinapinic acid $(10 \mathrm{~g} / \mathrm{L})$ in a $1: 1(\mathrm{v} / \mathrm{v})$ ratio. The complex was directly deposited onto the sample plate, dried in air, and then subjected to analysis on a 4800 MALDI TOF/ TOF MALDI-TOF/TOF mass spectrometer (Applied Biosystems, Foster City, CA). To obtain a stable signal, a typical mass spectrum was constructed by averaging 1800 laser shots followed by noise reduction and Gaussian smoothing using Data-Explorer software (Applied Biosystems). The MALDI-TOF MS analysis was acquired with an Nd-YAG laser $(355 \mathrm{~nm})$ operating at a repetition rate of $200 \mathrm{~Hz}$. The spectra were recorded in the linear mode using an accelerating voltage of $20 \mathrm{kV}$, a $19 \%$ grid voltage, a low-mass gate of $10 \mathrm{kDa}$, and a 630 ns delay time. The protein mixture of cytochrome $c$ $(12361 \mathrm{Da})$ and myoglobin (16952 Da) was used as an external mass calibration reference.

\section{Acknowledgements}

We thank the National Science Council and the Council of Agriculture, Taiwan, for financial support and thank Dr. Che Alex Ma and Dr. Jia-Tsrong Jan (The Genomics Research Center, Academia Sinica) for their gifts of HA proteins and recombinant $\mathrm{H} 5 \mathrm{~N} 1$ viruses.

\section{Author details}

'Department of Chemistry, National Taiwan University, Taipei, 106, Taiwan. ${ }^{2}$ Institute of Chemistry, Academia Sinica, Taipei, 115, Taiwan. ${ }^{3}$ Department of Chemistry, National Central University, Jhong-Li, 320, Taiwan. ${ }^{4}$ Department of Veterinary Medicine, National Taiwan University, Taipei, 106, Taiwan. ${ }^{5}$ The Genomics Research Center, Academia Sinica, Taipei, 115, Taiwan.

\section{Authors' contributions}

YJC and JMF are the principal investigators and take primary responsibility for the paper. TCC synthesized magnetic nanoparticles with antibody conjugation and performed the magnetic separation of influenza virus. WH 
conducted SDS-PAGE and MALDI-TOF MS analyses. CHW instructed the preparation of monoclonal antibody and influenza virus samples. YJC instructed the biochemical analyses and wrote the manuscript. JMF instructed the chemical synthesis and also wrote the manuscript. All authors have read and approved the final manuscript.

\section{Competing interests}

The authors declare that they have no competing interests.

Received: 6 July 2011 Accepted: 16 November 2011

Published: 16 November 2011

\section{References}

1. Wilson IA, Skehel JJ, Wiley DC: Structure of the hemagglutinin membrane glycoprotein of influenza virus at $3 \AA$ resolution. Nature 1981, 289:366-373.

2. Wilson IA, Cox NJ: Structural basis of immune recognition of influenza virus hemagglutinin. Annu Rev Immunol 1990, 8:737-771.

3. Moscona A: Neuraminidase Inhibitors for Influenza. N Engl J Med 2005, 353:1363-1373

4. De Clercq E: Antiviral agents active against influenza A viruses. Nat Rev Drug Discov 2006, 5:1015-1025.

5. Lagoja IM, De Clercq E: Anti-influenza virus agents: synthesis and mode of action. Med Res Rev 2008, 28:1-38.

6. World Health Organization: Recommendations and laboratory procedures for detection of avian influenza $\mathrm{A}(\mathrm{H} 5 \mathrm{~N} 1)$ virus in specimens from suspected human cases. 2007 [http://www.who.int/influenza/resources/ documents/h5n1_laboratory_procedures/en/].

7. Quan PL, Briese T, Palacios G, Lipkin WI: Rapid sequence-based diagnosis of viral infection. Antiviral Res 2008, 79:1-5.

8. Evaluation of rapid influenza diagnostic tests for detection of novel influenza A (H1N1) virus - United States. CDC Morbidity and Mortality Weekly Report 2009, 58:826-829[http://www.cdc.gov/mmwr/preview/ mmwrhtml/mm5830a2.htm?s_cid].

9. Vinikoor M, Stevens J, Nawrocki J, Singh K: Influenza A virus subtyping: paradigm shift in influenza diagnosis. J Clin Microbiol 2009, 47:3055-3056.

10. Woolcock PR, Cardona CJ: Commercial immunoassay kits for the detection of influenza virus type A: evaluation of their use with poultry. Avian Dis 2005, 49:477-481.

11. Zhang A, Jin AM, Liu F, Guo X, Hu Q, Han L, Tan Y, Chen H: Development and evaluation of a DAS-ELISA for rapid detection of avian influenza viruses. Avian Dis 2006, 50:325-330.

12. He Q, Velumani S, Du Q, Chee WL, Fook KN, Donis R, Kwang J: Detection of $\mathrm{H} 5$ avian influenza viruses by antigen-capture enzyme-linked immunosorbent assay using $\mathrm{H} 5$-specific monoclonal antibody. Clin Vaccine Immunol 2007, 24:617-623.

13. Chen $\mathrm{YC}$, Chen $\mathrm{CH}$, Wang $\mathrm{CH}$ : $\mathrm{H} 5$ antibody detection by blocking enzyme-linked immunosorbent assay using a monoclonal antibody. Avian Dis 2008, 52:124-129.

14. Mandenius CF, Wang R, Aldén A, Bergström G, Thébault S, Lutsch C, Ohlson S: Monitoring of influenza virus hemagglutinin in process samples using weak affinity ligands and surface plasmon resonance. Anal Chim Acta 2008, 623:66-75.

15. Yan X, Zhong W, Tang A, Schielke EG, Hang W, Nolan JP: Multiplexed flow cytometric immunoassay for influenza virus detection and differentiation. Anal Chem 2005, 77:7673-7678.

16. Liu S, Chen G, Zhou Q, Wei Y: An immuno-biosensor system based on quartz crystal microbalance for avian influenza virus detection. Proc SPIE 2008, 67943P.

17. Kiselar JG, Downard KM: Antigenic surveillance of the influenza virus by mass spectrometry. Biochemistry 1999, 38:14185-14191.

18. Downard KM, Morrissey B, Schwahn AB: Mass spectrometry analysis of the influenza virus. Mass Spect Rev 2009, 28:35-49.

19. Schwahn $A B$, Wong WH, Downard KM: Subtyping of the influenza virus by high resolution mass spectrometry. Anal Chem 2009, 81:3500-3506.

20. Townsend MB, Dawson ED, Mehlmann M, Smagala JA, Dankbar DM Moore CL, Smith CB, Cox NJ, Kuchta RD, Rowlen KL: Experimenta evaluation of the FluChip diagnostic microarray for influenza virus surveillance. J Clin Microbiol 2006, 44:2863-2871.

21. Dawson ED, Moore CL, Dankbar DM, Mehlmann M, Townsend MB, Smagala JA, Smith CB, Cox NJ, Kuchta RD, Rowlen KL: Identification of A/
H5N1 influenza viruses using a single gene diagnostic microarray. Anal Chem 2007, 79:378-384.

22. Wang LC, Pan CH, Severinghaus LL, Liu LY, Chen CT, Pu CE, Huang D, Lir JT, Chin SC, Cheng MC, Lee SH, Wang CH: Simultaneous detection and differentiation of Newcastle disease and avian influenza viruses using oligonucleotide microarrays. Vet Microbio/ 2008, 127:217-226.

23. Maines TR, Jayaraman A, Belser JA, Wadford DA, Pappas C, Zeng H, Gustin KM, Pearce MB, Viswanathan K, Shriver ZH, Raman R, Cox NJ, Sasisekharan R, Katz JM, Tumpey TM: Transmission and pathogenesis of swine-origin $2009 \mathrm{~A}(\mathrm{H} 1 \mathrm{~N} 1)$ influenza viruses in ferrets and mice. Science 2009, 325:484-487

24. Childs RA, Palma AS, Wharton S, Matrosovich T, Liu Y, Chai W, CampaneroRhodes MA, Zhang Y, Eickmann M, Kiso M, Hay A, Matrosovich M, Feizi T: Receptor-binding specificity of pandemic influenza A (H1N1) 2009 virus determined by carbohydrate microarray. Nat Biotechnol 2009, 27:797-799.

25. Wang CC, Chen JR, Tseng YC, Hsu CH, Hung YF, Chen SW, Chen CM, Khoo KH, Cheng TJ, Cheng YS, Jan JT, Wu CY, Ma C, Wong CH: Glycans on influenza hemagglutinin affect receptor binding and immune response. Proc Natl Acad Sci USA 2009, 106:18137-18142.

26. Liao HY, Hsu CH, Wang SC, Liang $\mathrm{CH}$, Yen HY, Su CY, Chen $\mathrm{CH}$, Jan JT, Ren $\mathrm{CT}$, Chen $\mathrm{CH}$, Cheng TJR, Wu CY, Wong CH: Differential receptor binding affinities of influenza hemagglutinins on glycan arrays. J Am Chem Soc 2010, 132:14849-14856.

27. Hutchens TW, Yip TT: New desorption strategies for the mass spectrometric analysis of macromolecules. Rapid Commun Mass Spectr 1993, 7:576-580.

28. Nelson RW, Krone JR, Bieber AL, Williams P: Mass spectrometric immunoassay. Anal Chem 1995, 67:1153-1158.

29. Nedelkov D, Tubbs KA, Niederkofler EE, Kiernan UA, Nelson RW: Highthroughput comprehensive analysis of human plasma proteins: a step toward population proteomics. Anal Chem 2004, 76:1733-1737.

30. Nedelkov D, Kiernan UA, Niederkofler EE, Tubbs KA, Nelson RW: Investigating diversity in human plasma proteins. Proc Natl Acad Sci USA 2005, 102:10852-10857.

31. Hsing $I M, X u Y, Z$ hao $W$ : Micro- and nano-magnetic particles for applications in biosensing. Electroanalysis 2007, 19:755-768.

32. Gupta AK, Naregalkar RR, Vaidya VD, Gupta M: Recent advances on surface engineering of magnetic iron oxide nanoparticles and their biomedical applications. Nanomedicine 2007, 2:23-39.

33. Sun C, Lee JSH, Zhang M: Magnetic nanoparticles in MR imaging and drug delivery. Adv Drug Delivery Rev 2008, 60:1252-1265.

34. Jun YW, Lee JH, Cheon J: Chemical design of nanoparticle probes for high-performance magnetic resonance imaging. Angew Chem Int Ed 2008, 47:5122-5135.

35. McCarthy JR, Weissleder R: Multifunctional magnetic nanoparticles for targeted imaging and therapy. Adv Drug Delivery Rev 2008, 60:1241-1251.

36. Chou PH, Chen SH, Liao HK, Lin PC, Her GR, Lai ACY, Chen JH, Lin CC, Chen YJ: Nanoprobe-based affinity mass spectrometry for selected protein profiling in human plasma. Anal Chem 2005, 77:5990-5997.

37. Lin PC, Chou PH, Chen SH, Liao HK, Wang KY, Chen YJ, Lin CC: Ethylene glycol-protected magnetic nanoparticles for a multiplexed immunoassay in human plasma. Small 2006, 2:485-489.

38. Lin PC, Tseng MC, Su AK, Chen YJ, Lin CC: Functionalized magnetic nanoparticles for small-molecule isolation, identification, and quantification. Anal Chem 2007, 79:3401-3408.

39. Wang KY, Chuang SA, Lin PC, Huang LS, Chen SH, Ouarda S, Pan WH, Lee PY, Lin CC, Chen YJ: Multiplexed immunoassay: quantitation and profiling of serum biomarkers using magnetic nanoprobes and MALDITOF MS. Anal Chem 2008, 80:6159-6167.

40. Kang YS, Risbud S, Rabolt JF, Stroeve P: Synthesis and characterization of nanometer-size $\mathrm{Fe}_{3} \mathrm{O}_{4}$ and $\gamma-\mathrm{Fe}_{2} \mathrm{O}_{3}$ particles. Chem Mater 1996, 8:2209-2211

41. Chen $\mathrm{YC}$, Chen $\mathrm{CH}$, Wang $\mathrm{CH}$ : $\mathrm{H} 5$ antibody detection by blocking enzyme-linked immunosorbent assay using a monoclonal antibody. Avian Dis 2008, 52:124-129.

42. Schreyeck $L$, Wlosik $A$, Fuzellier $H$ : Influence of the synthesis route on $\mathrm{MgAl}_{2} \mathrm{O}_{4}$ spinel properties. J Mater Chem 2001, 11:483-486.

43. Webster RG: Estimation of the molecular weights of the polypeptide chains from the isolated hemagglutinin and neuraminidase subunits of influenza viruses. Virology 1970, 40:643-654. 
44. Schulze IT: The biologically active proteins of influenza virus: the hemagglutinin. In The influenza virus and influenza. Edited by: Kilbourne ED. Academic Press, New-York; 1975:53-83.

45. Skehel JJ, Waterfield MD: Studies on the primary structure of the influenza virus hemagglutinin. Proc Natl Acad Sci USA 1975, 72:93-97.

46. Chen MW, Cheng TJR, Huang Y, Jan JT, Ma SH, Yu AL, Wong CH, Ho DD: A consensus-hemagglutinin-based DNA vaccine that protects mice against divergent H5N1 influenza viruses. Proc Natl Acad Sci USA 2008, 105:13538-13543.

47. Zheng YZ, Webb R, Greenfield PF, Reid S: Improved method for counting virus and virus like particles. J Virol Methods 1996, 62:153-159.

48. Reed $\mathrm{L}$, Muench $\mathrm{H}$ : A simple method of estimating fifty percent endpoints. Am J Hyg 1938, 27:493-497.

49. Bradford MM: A rapid and sensitive method for the quantitation of microgram quantities of protein utilizing the principle of protein-dye binding. Anal Biochem 1976, 72:248-254.

doi:10.1186/1477-3155-9-52

Cite this article as: Chou et al: Rapid and specific influenza virus detection by functionalized magnetic nanoparticles and mass spectrometry. Journal of Nanobiotechnology 2011 9:52.

\section{Submit your next manuscript to BioMed Central} and take full advantage of:

- Convenient online submission

- Thorough peer review

- No space constraints or color figure charges

- Immediate publication on acceptance

- Inclusion in PubMed, CAS, Scopus and Google Scholar

- Research which is freely available for redistribution

Submit your manuscript at www.biomedcentral.com/submit 